\title{
Pituitary Stem/Progenitor Cells: Their Enigmatic Roles in Embryogenesis and Pituitary Neoplasia - A Review Article
}

\section{Aydin Sav*}

Department of Pathology, Acibadem University, School of Medicine, Atasehir, Istanbul, Turkey

\begin{abstract}
Although the hypothalamus is the master regulator, it is appropriate terming the pituitary gland as the conductor of endocrine orchestra of the human body. The existence of pituitary stem cells in the adult pituitary gland is supported by such findings as postnatal proliferation, differentiation based on environmental alterations, and development of hormoneproducing cells after specific lesions in the pituitary. Stem cell characteristics, including renewal, proliferation abilities, and the presence of stem cells markers, have been demonstrated in adult pituitary cells from mammals. Research into the capacity of "pituitary stem cells" to differentiate in vitro and in vivo will clarify the regulatory mechanisms of these cells. The characteristics of stem cells include self-renewal capacity, lack of specialization, and pluripotency with the ability to differentiate into different cell phenotypes. Adult pituitary cell lineages might have a pituitary stem cell role and the potential participation of these cells in pituitary tumorigenesis. Inevitably numerous questions remain to be resolved, and future challenges are enormous. Therefore, this review provides a comprehensive overview of the motivating recent developments in the pituitary stem cell exploration. The latest expansion in pituitary stem cell research may commence a stimulating period in the pituitary embryology and pathology.
\end{abstract}

Keywords: Adenohypophysis; Adenoma; $\beta$-catenin; $\beta$-catnc; Biomarker; Bmi-1; CD133; CDKN1C; Corticotropes; E-cadherin (Cdh1); EMA; Galectin-3; GFRa2 protein; Gonadotrophs; GPS cells (GFRa2/Prop1/stem cells); Kip2; Klf4; Jag1; Jag2; Lactotropes Nanog; Nestin; Notch 2; Notch3; Oct-4; P57; Pax6; Pit1; Pituisphere; Pituitary; Pituitary stem/progenitor cells; Prop1; Psoriasin; S100; Sca-1; side population (SC-SP); Somatotropes; Sox2; Sox2+/E-cadherin+ stem cells; Sox-9; Stem cell; TCF3; Thyrotrophs; Tumour

Abbreviations: AP: Anterior Pituitary; Cscs: Cancer Stem Cells; ACTH: Adreno Corticotropic Hormone; ESCs: Embryonic Stem Cells; EGF: Epidermal Growth Factor; EMT: Epithelial-Mesenchymal Transition; FSC: Folliculostellate Cell; GDNF; Glial Cell Line-Derived Neurotrophic Factor; FSH/LH: Follicle-Stimulating Hormone/ Luteinizing Hormone; PRL: Prolactin; MSH: Melanocyte Stimulating Hormone; Nscs: Neural Stem Cells; NTN: Neurturin; RP: Rathke's Pouch; GH: Growth Hormone; TSH: Thyroid Stimulating Hormone

\section{Introduction}

In this article recent advance on pre and postnatal stem cells, stem cells in adult life, transdifferentiation of anterior pituitary (AP) cells, folliculostellate cells (FSCs) and stemness markers and biomarkers of pituitary cytogenesis were reviewed. In each subtitle impact of the specific markers and cellular reactions of stem cells were addressed in the light of recent cellular and molecular researches.

\section{Pre and postnatal stem cells}

Pituitary gland plays an important role in such vital physiological processes as growth, reproduction, metabolism, and immune response. The adenohypophysis, the secretory anterior lobe of the gland, contains 5 different types of hormone-secreting cells: Lactotropes (prolactin secreting cells), Somatotropes (growth hormone secreting cells), Corticotropes (adrenocorticotropic hormone secreting cells), Gonadotropes (follicle-stimulating hormone/luteinizing hormone secreting cells), and Thyrotropes (thyroid stimulating hormone secreting cells) [1]. Pituitary gland of newborns already presents a full set of terminally differentiated hormone-producing cells $[1,2]$. Surprisingly, how these hormonal cells are formed or renewed during postnatal life remains largely unsolved [3]. However, postnatal gland undergoes extensive remodeling during one's lifetime. Soon after birth, adenohypophysis enters a phase of growth that results in a dramatic increase in the size of the gland [4]. Adult pituitary gland has the ability to adapt its cellular composition in response to changing physiological conditions, and this ability is thought to be mediated via the hypothalamus. For instance, the total number of GH-secreting cells doubles during puberty, where as the number of PRL-secreting cells expands and contracts several-fold during pregnancy, lactation, and weaning [4]. The pituitary gland also appears to repopulate cells after tissue loss $[5,6]$. Proposed mechanisms include mitoses of differentiated cells, transdifferentiation between phenotypes, and the differentiation of pituitary stem cells [7]. However, there is no conclusive in vivo evidence that any of these processes actually occur. The existence of pituitary stem cells in the adult pituitary gland is supported by such findings as postnatal proliferation, differentiation based on environmental alterations, and development of hormone-producing cells after specific lesions in the pituitary $[5,6]$. Stem cell characteristics, including renewal, proliferation abilities, and the presence of stem cells markers, have been demonstrated in adult pituitary cells of mammals [6]. However, the proliferation ability observed so far is limited, and the potential of differentiation into hormone-secreting cells remains to be conclusively proven $[6,8]$ (Figure 1).

Pituitary stem cells only come into play under more extreme conditions such as injury (so-called facultative stem cells). From the currently available data, embryonic developmental programs seem to be

${ }^{*}$ Corresponding author: Aydin Sav, Acibadem University, School of Medicine Department of Pathology, Kerem Aydinlar Yerleskesi, Icerenkoy Mahallesi, Kayisdagi Caddesi, No: 32, Atasehir, Istanbul, Turkey, Tel: 90216386 3941; Fax: 90.216.3775357; E-mail: murataydinsav@gmail.com

Received December 10, 2013; Accepted January 23, 2014; Published January 26, 2014

Citation: Sav A (2014) Pituitary Stem/Progenitor Cells: Their Enigmatic Roles in Embryogenesis and Pituitary Neoplasia - A Review Article. J Neurol Disord 2: 146. doi:10.4172/2329-6895.1000146

Copyright: (C) 2014 Sav A. This is an open-access article distributed under the terms of the Creative Commons Attribution License, which permits unrestricted use, distribution, and reproduction in any medium, provided the original author and source are credited. 


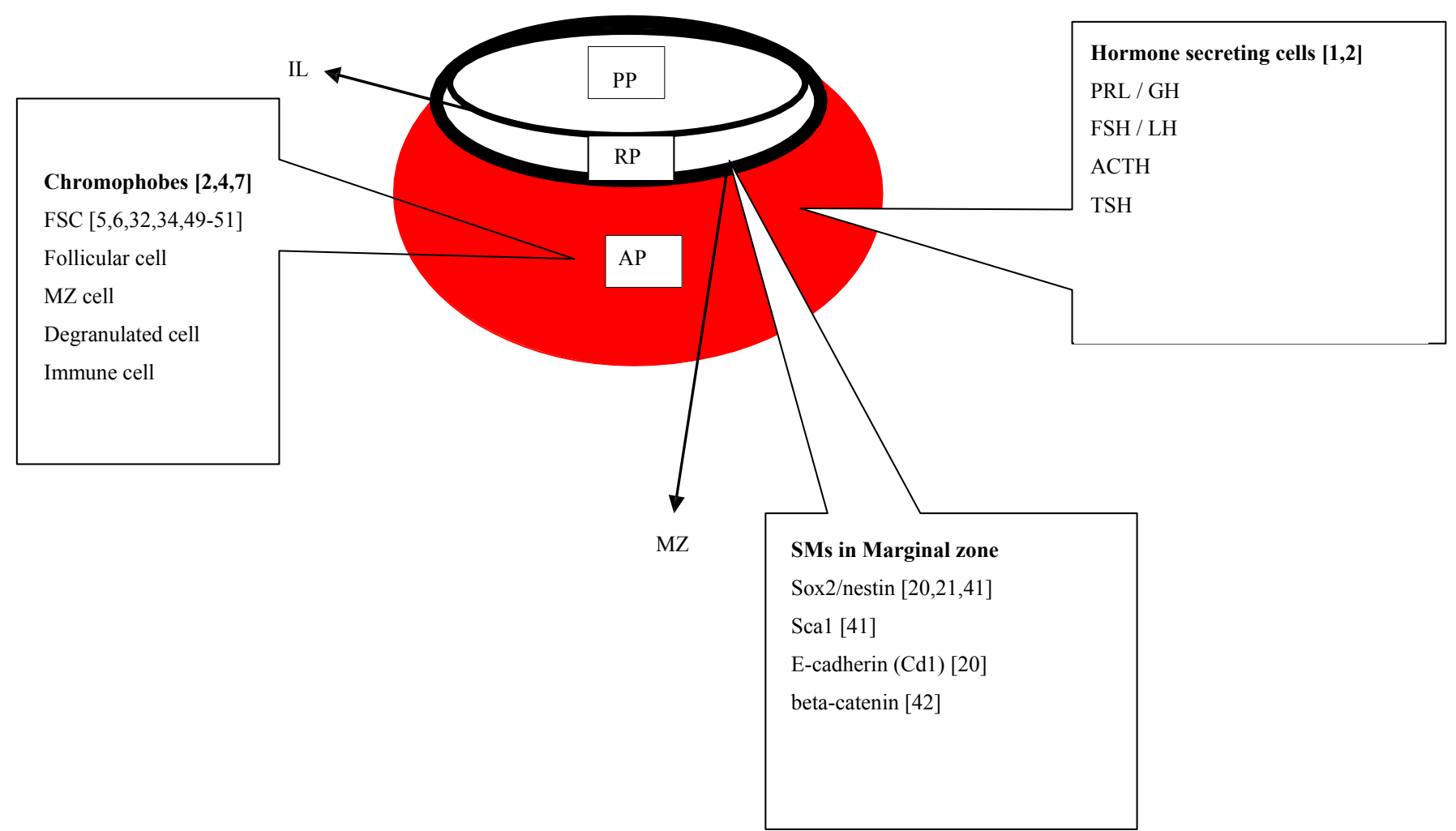

Figure 1: Distribution of hormonal and stemness markers (SM) in different topographic areas of pituitary gland. Anterior pituitary and its specific topographic site marginal zone bear different cell types including hormone secreting and non-hormone-secreting (chromophobes) cells. (AP, anterior pituitary IL, intermediate lobe; MZ, marginal zone; PP, posterior pituitary; RP, Rathke's pouch).

re-used during postnatal stem cell differentiation [3]. Stem cell markers have also been detected in animal models of pituitary tumorigenesis [8]. However a direct connection has not been demonstrated so far. Upcoming research about the capacity of "pituitary stem cells" to differentiate in vitro and in vivo will clarify the mechanisms for regulation of these cells. Recent stem cell researches shed light on molecular and physiologic mechanisms which most likely to be used in management of pituitary adenomas and the implantation of pituitary stem cells for hormonal deficiencies [9]. Alternatively stem cells may offer life-long cures for genetically, environmentally and/or surgically induced pituitary deficiencies [3].

\section{Stem cells in adult life}

Recent data supports the role of stem cells in the repair and plasticity of different organs in the human body such as the heart and brain $[10,11,12]$. These specific cells in these organ systems have displayed the fundamental characteristics of a stem cell. Among the characteristics include self-renewal capacity, lack of specialization, and pluripotency with the ability to differentiate into different cell phenotypes $[3,6,11]$. Stem cells possess multipotent differentiation capacity to generate the desired tissue cell types $[11,13]$. Initially stem cells give rise to daughter (progenitor) cells that proliferate to expand as a pool of transitamplifying cells, which further perpetrate to precursor cells those of which differentiate and specialize to compensate pituitary cells $[14,15]$. Besides these cells characteristically form into sphere like structures and, in the example of neural stem cells (NSCs), are called neurospheres. In culture, the stem cells form colonies of undifferentiated, pluripotent cells that contain unique stem cell surface, cytoplasmic, and nuclear markers. Similar to these other organ systems, the plasticity of the pituitary gland and its alterations during adult life may be secondary to the activity of adult stem cells present in the gland [5,16-22]. Stem cell markers such as Sox-2 [20], nestin [21], Sca-1 [21], and CD133 [23] have been identified in subpopulations of cells in the adult pituitary gland of animal models $[23,24]$. In addition, "pituispheres" have been generated in vitro in these models [17,19]. These findings support a potential role for pituitary stem cells in adult pituitary plasticity. It is clear that the proposed models are still hypothetical on many points, and will need further thorough investigation and experimental support. So far the distinctive problem is the topographic network of newborn cells in addition to their functional incorporation into the presented homo- and/or heterotypic cell networks [3]. Pituitary stem cells express several stemness markers (such as Sox2) and pituitary-embryonic factors (such as Prop1), and that they prominently occupy the marginal zone around the cleft, the residual lumen of the adenohypophyseal primordium Rathke's pouch (RP) [25]. Concisely pituitary stem cells, studies are only now beginning to address their role and participation, particularly in processes of postnatal pituitary maturation, repair and pathology [3] (Table 1).

Apart from hormone producing cells of adenohypophysis, there is a substantial cohort of cells that lack hormonal markers $[2,4,7,23]$. This group of cells with non-hormone-secreting properties are referred as chromophobes. They are non reactive with periodic acid-Schiff stain since they are devoid of secretory hormone containing granules. In the late sixties the pioneer experimental studies by Yoshimura et al. showed the chromophobes acting as pituitary stem cells $[7,23]$. In this study, chromophobes were purified from 1-year-old mice and transplanted in the hypophysiotrophic area of the hypothalamus after surgical resection of the animal's own pituitary gland. The authors reported that 


\begin{tabular}{|c|c|}
\hline \multicolumn{2}{|c|}{ SMs in Embryonic Phase } \\
\hline Marker & References \\
\hline Oct-4 & $5,6,50,51$ \\
\hline Sox2 & $5,6,50,51$ \\
\hline Nanog & $5,6,50,51$ \\
\hline Wnt/ b-beta-catenin & 69 \\
\hline Pax6 & $70-75$ \\
\hline Lhx4 & $70-75$ \\
\hline Prop1 & $25,70-75$ \\
\hline Otx2 & $55,70-75$ \\
\hline Notch2 & $70-75$ \\
\hline Notch3 & $70-75,78$ \\
\hline Non Sca1 high & $70-75$ \\
\hline
\end{tabular}

\begin{tabular}{|c|c|}
\hline \multicolumn{2}{|c|}{ SMs in Adult Pituitary } \\
\hline Marker & References \\
\hline CD133 & 22 \\
\hline Oct-4 & 22 \\
\hline Nanog & 22 \\
\hline Nestin & 22 \\
\hline Bmi-1 & 22 \\
\hline Jag1 & $25,41,76$ \\
\hline Notch2/3 & 79 \\
\hline Hes1 & $25,41,76$ \\
\hline Hey1 & $25,41,76$ \\
\hline Pit-1 & $3,54,83$ \\
\hline Prop1 & 54 \\
\hline P57 & 25 \\
\hline P27 & 25 \\
\hline
\end{tabular}

Table 1: Distribution of stemness markers in embryonic and adult phases of pituitary gland. Various stemness markers in different phases of pituitary gland are depicted in pertinent references within the manuscript.

pituitary like structures formed via proliferation and differentiation of chromophobes into acidophils and basophils [7,23].

In a follow-up study by Otsuka et al., [26] chromophobes differentiated in vitro into mature acidophils and basophils after the addition of hypothalamic hormones. However, the authors were unable to demonstrate one of the fundamental characteristics of a stem cell: the capacity of one single cell to originate more than one lineage of cells. The failure to demonstrate pluripotency may be partially explained by the heterogeneity of the cell group classified as chromophobes. This group includes agranular cells such as folliculostellate cells [FSC], follicular cells, marginal zone cells, degranulated hormonal cells, and mesenchymal and immune cells [5] (Figure 1).

Agranular cells have the ability to differentiate into acidophils and basophils $[7,23,26]$ supports the hypothesis that chromophobes might display stem cell characteristics [5]. However, only a small subpopulation of chromophobes actually displays these characteristics $[5,6,7,23]$. Therefore, the individual study of such cells as FS cells, follicular cells, or marginal cells represents the current trend in pituitary stem cell research in an attempt to identify this subpopulation $[5,23]$.

The presence of minimal mitotic activity in occurrence of plurihormonal and null cell-type adenomas and in the hyperplastic pituitary gland support the hypothesis that pituitary stem cells are potential cellular source for pituitary adenomas [27]. Alterations in the hormonal environment might be associated with changes in the normal pattern of growth/differentiation of these cells and therefore promote pituitary tumorigenesis.

The majority of the pituitary pathophysiology data have been obtained in animal models. The study of human pituitary tissue still presents several limitations, including lack of functional human cell lines in culture, the anatomic inaccessibility of the pituitary gland, unique murine tumor growth characteristics and paucity of reliable animal models, and $[23,27]$. For instance, the higher mitotic activity and expansion of murine pituitary tissue must be considered before the results are analyzed and extrapolated as a representation of the human pituitary gland $[23,28]$. However, animal studies have provided important information about pituitary physiology and the mechanisms of pituitary tumorigenesis. It is discussed which adult pituitary cell lineages might have a pituitary stem cell role and the potential participation of these cells in pituitary tumorigenesis. In addition, some researchers propose possible future clinical applications like the development of new treatment strategies for pituitary adenomas and hormone deficiencies [23,27].

\section{Transdifferentiation of anterior pituitary (AP) cells}

The majority of anterior pituitary is formed by chromophobes those of which have differentiation capacity into mature acidophils and basophils after the addition of hypothalamic hormones. This group includes agranular cells such as folliculostellate cells, follicular cells, marginal zone cells, degranulated hormonal cells, and mesenchymal and immune cells [6]. The heterogeneous ability of agranular cells to differentiate into acidophils and basophils $[7,26]$ supports the hypothesis that chromophobes might display stem cell characteristics [6]. However only a small subpopulation of chromophobes actually display these characteristics $[5,6,7]$. Therefore, the individual studies of these cells such as folliculostellate cells, follicular cells, or marginal cells represent the current trend in pituitary stem cell research in an attempt to identify these subpopulations [29].

\section{Folliculostellate cells (FSCs)}

Ultrastructural features of follicular structures reveal elongate or stellate cells (folliculo-stellate cells) attached to each other via terminal bars at their apical surface and by desmosomes at their lateral cell membranes that form major parts of the adenohypohyseal parenchyma $[30,31]$. FSCs occupy an approximately central position within every acinus in the adult human gland. Electron microscopically, these specific cells are furnished with a small nucleus and inconspicuous nucleolus, numerous free cytoplasmic polyribosomes but scant rough endoplasmic reticulum (RER), small Golgi apparatus. Additionally there might be a few intermediate filaments, and/or glycogen particles. Immunohistochemically, they are immunoreactive for S-100 and for GFAP [32-34]. Unfortunately, these immunoreactivity patterns are not coexisting and are only temporary as related to phases of the FSC life cycle. Lately, it was found that these cells are also immunoreactive with EMA and galectin-3 $[35,36]$.

Due to a wide variety of perplexing capacities of stem cells from hormone production to immune roles, coupled with morphologic variations some investigators supposed dual derivation of FSC: pituitary and hemopoetic (dendritic cells) $[23,37]$. In a detailed study in which electron microscopic and ultrastructural immunocytochemical analyses were used, it was well documented formation of follicles within the pituitary primordium with stubby villi filling most of small lumina were noticeable as early as 6 weeks of gestation [38]. Later (8-10 weeks 
of gestation), the morphology of the follicles is not much different from that of what is seen in the adult gland. In the fetal gland the follicles may contain FSC possessing a few small secretory granules, fulfilling the criteria of endocrine differentiation, but not more differentiated forms $[23,38]$.

Structural evolution of pituitary acinus is incessantly ongoing in distinctive developmental phases of antenatal and postnatal life $[23,30]$. The newborn adenohypophysis contains no cells immunoreactive for S-100 or GFAP. Soon after a number of GFAP-positive cells appear in the cleft area, within the small embryonic remnants of the Rathke's pouch. The late appearance of S-100 and GFAP immunoreactivities most likely results from the previously described mechanism [30]. Follicles are not static structures: new FSC are formed by glandular cells around single-cell necroses by forming terminal bars and desmosomes, in this manner isolating the debris [30]. Subsequently, they dismantle their endocrine machinery, taking up the non-endocrine phenotype of FSC. This process was interpreted to be ubiquitous as well as reversible [39]. This particular reversibility most probably may be explained as both becoming a progenitor null cell followed by differentiation to participate in tissue repair or in hyperplastic processes, and tumorigenesis $[23,39]$.

As for extensive use of immunohistochemistry, EM, and immunoelectron microscopy enlightened the concept of inflexible one cell-one hormone, thus 5-cell-type model. Therefore, using of modern techniques and new horizons in understanding of new adenoma types and previously undisclosed cell types belonging to or resident in the human adenohypophysis [23,40]. So far, not only morphologic, in vitro biochemical, and genetic data but neoplastic potential make the small FSC more than just an equal member of the pituitary cell population: it emerges into a pluripotent pituitary-specific adult stem cell $[23,39]$.

\section{Stemness markers and biomarkers of pituitary cytogenesis}

Numerous biomarkers of having different effects either in pituitary embryogenesis and tumor development are designated as stemness markers. This perplexing group consists of several constituents, i.e. nestin, Sca1, Sox2+/E-cadherin, S100 proteins, Prop-1, GFRa2, Oct-4, Bmi-1, CD133, beta-catenin, SOX2, Pax6, Notch2, Notch3, Pit1, p57 and cancer stem cells.

Nestin has been found expressed in some stem (Sox $2+$ ) cells in situ (marginal zone) and in culture (pituispheres) by a number of investigators [20,21,41] but not by others [42]. Certainly, nestin is not restricted to the pituitary stem cells but shows a heterogeneous expression pattern in the pituitary's non-hormonal cell population, including in some pericytes $[5,6,43]$.

Sca1-(Stem Cell Antigen 1) another marker that seems contentious is Sca1, not or only modestly expressed in the stem cell-enriching side population (SC-SP) fraction [41] but immunodetected in pituispheres [20] and in a subpopulation of colony-forming cells [44]. However, the role of Sca1 expressivity in the pituitary and its tumors remains to be shown.

Sox $2+/ E-c a d h e r i n+$ stem cells start to express Sox9, nestin and/ or S100 as well as Prop1 during their transition to the progenitor phase, and subsequently loose expression of these markers before or during terminal differentiation to the hormonal cells. E-cadherin is a tumor suppressor gene $[45,46]$ and a classical member of the cadherin superfamily. Cadherins act so structural cell glue, regulate signaling pathways that organize cell proliferation and motility which is fundamentally driven by the process of epithelial-mesenchymal transition (EMT) [3]. Loss of E-cadherin function or expression has been implicated in cancer progression and metastasis [47]. Marginal cells facing the Rathke's cleft and hormone negative but $\mathrm{S} 100+$ cells within AP lobe strongly express E-cadherin (Cdh1)[20]. E-Cadherins promote coordinated actions to changing endocrine needs and conditions [48].

S100 proteins have been implicated in a variety of intracellular and extracellular functions [49]. S100 proteins are involved in regulation of transcription factors, $\mathrm{Ca}++$ homeostasis, protein phosphorylation, the dynamics of cytoskeleton constituents, cell growth and differentiation, enzyme activities, and the inflammatory response. S100A7 (psoriasin) and S100A15 have been found to act as cytokines in inflammation, particularly in autoimmune skin conditions such as psoriasis [49]. Follicostellate cells of pituitary display diverse nuclear and cytoplasmic S100 reactivity FSCs are presumed to be the analogs of brain glial cell lineage $[5,6,50,51]$.

Prop1: Homeobox protein prophet of PIT-1 is a protein that in humans is encoded by the PROP1 gene [52]. PROP1 has both DNAbinding and transcriptional activation ability. Its expression leads to ontogenesis of pituitary gonadotropes, as well as somatotropes, lactotropes, and caudomedial thyrotropes. Inactivating mutations in PROP1 result in deficiencies of luteinizing hormone (LH), folliclestimulating hormone (FSH), growth hormone $(\mathrm{GH})$, prolactin (PRL), and thyroid-stimulating hormone (TSH) [52]. In pituitary genetic inactivation of Prop1 results in failure of embryonic progenitors to leave the dorsal proliferative region of RP for further differentiation and colonization of the developing AP [53]. One of the optional functions of Prop1 is playing a pivotal role for cells differentiating from the stem cell cohort into the differentiating zone of the gland. It is a compulsive marker for transition of stem cells from the in-gland Sox $2+$ cell clusters to the neighboring pituitary parenchyma [54].

GFRa2 protein is a glycosylphosphatidylinositol (GPI)-linked cell surface receptor. It is a part of the GDNF receptor family. Glial cell line-derived neurotrophic factor (GDNF) and neurturin (NTN) are two structurally related, potent neurotrophic factors that play key roles in the control of neuron survival and differentiation. They both bind the GFRA2 receptor [55].

Oct-4 (Octamer-binding transcription factor 4) is a homeodomain transcription factor of the POU family [56]. This protein is critically involved in the self-renewal of undifferentiated embryonic stem cells (ESC). It has often been used as a marker of stemness, as differentiated cells show reduced expression of this marker. Several studies suggest a role for Oct- 4 in sustaining self-renewal capacity of adult somatic stem cells (i.e. stem cells from epithelium, bone marrow, liver, pituitary, etc.) [57]. Oct- 4 has also been implicated as a marker of cancer stem cells (CSCs). Oct-4, Sox2, and Nanog, and Klf4 constitutes the pluripotency transcription-factor core of embryonic stem (ES) cells [5,6,50,51].

Bmi-1: The Polycomb group transcriptional repressor Bmi-1 was discovered as a common oncogene activated in lymphoma [58], specifically regulate HSCs [59] and neural stem cells [60]. Human pituitary adenomas also show Bmi-1 overexpression in about half of the cases so the stem cell marker Bmi-1 could be included in pituitary neoplasia [61].

CD133 originally known as AC133 [62]. CD133 is a glycoprotein also known in humans and rodents as Prominent 1 (PROM1) [63]. It is a member of pentaspan transmembrane glycoproteins (5-transmembrane, 5-TM), which specifically localize to cellular protrusions. CD133 is expressed in hematopoietic stem cells [64], 
endothelial progenitor cells [65], glioblastoma, neuronal and glial stem cells [66], various pediatric brain tumors [66] as well as adult kidney, mammary glands, trachea, salivary glands, placenta, digestive tract, testes, and some other cell types [67]. After analyzing isolated stem/ progenitor-like cells from pituitary adenoma by the sphere method, the presence of expression of neuronal progenitor markers including CD133 supported CD133+ cells existence in pituitary adenomas [68].

Beta-catenin (or $\beta$-catenin) is a dual function protein, regulating the coordination of cell-cell adhesion and gene transcription. Its role in stem cell renewal is being one of the most important results of Wnt signaling and the elevated level of beta-catenin in certain cell types is the maintenance of pluripotency [69]. In other cell types and developmental stages, $\beta$-catenin may promote differentiation, especially towards mesodermal cell lineages. $\beta$-catenin constitutes an integral constituent of the classic cadherin complexes. Widespread membranous $\beta$-catenin is dispersed in AP extensively. It is intensely expressed in somatotropes as well as marginal zone [42]. $\beta$-catenin is not only accumulated in the nucleus and cytosol (nucleocytoplasmic beta-catenin or $\beta$-catnc) only in small clusters of cells during the pretumoral stage of late-embryonic and early-postnatal life, but in the subsequent phases virtually all tumor cells exhibits accumulation of $\beta$-catenin in the nucleus, cytoplasm or both [3].

Sox2: SRY (sex determining region Y)-box 2, also known as Sox2, is a transcription factor that is essential for maintaining selfrenewal, or pluripotency, of undifferentiated embryonic stem cells. Co-expression of nestin and Sox $2+$ in some stem cells (marginal zone) and in culture (pituispheres) was documented [20,21,41]. Prop1 is probably downregulated before stem cell differentiation enhances [3]. Sox 2 expression and side population (SP) phenotype assessed stem cell population is more profuse throughout the postnatal first week than in the next phases. Thereby higher proliferation rate and quicker differentiation capacity show an activated status as obtained from pituisphere cultures [48].

Pax6 serves as a regulator in the coordination and pattern formation required for differentiation and proliferation to successfully take place, ensuring that the processes of neurogenesis and oculogenesis are carried out successfully. As a transcription factor, Pax6 acts at the molecular level in the signaling and formation of the central nervous system. Pax6 as being a member of transcriptional regulators and signaling factors those have critical roles in early embryogenesis of the pituitary, (viz. Hesx1, Lhx4, Prop1, Pax6, Otx2, and specific Notch pathway components). Pax6 is also climaxes it expressivity in the nonScalhigh SP [70-75].

Notch 2 a member of the notch family. Notch family members play a role in a variety of developmental processes by controlling cell fate decisions. Notch signaling pathway has been identified in the embryonic periluminal progenitor zone $[73,75]$ as well as in the adult pituitary SC-SP (in particular Jag1, Notch2, Notch3, Hes1 and Hey1) $[25,41,76]$. Adult pituitary cells present prominent expression of several transcriptional, signaling and growth-regulatory factors previously thought to be restricted to the pituitary embryonic phase (such as Hesx1, Lhx4, Pax6, Prop1, Otx2, Notch2, Notch3 [25,41]. Notch receptors Notch1 and Notch2, and ligands Jag1 and Jag2 are not co localized with hormones but with S100 (except for Jag2) in about half of the (S100+) marginal cells [77].

Notch 3 gene encodes the third discovered human homologue of the Drosophilia melanogaster type I membrane protein notch. Transgenically activated Notch pilots to amplify Sox 2 immunoreactivity in the embryonic pituitary [78]. Suppression of Notch signaling results in a drop off in Sox2 expression and an increase in differentiated cells in other developing systems [79]. Notch signaling system in adult pituitary stem cells intensifies Prop1 and Sox 2 expression. It sustains self-renewal/proliferation of stem cells likewise in other adult tissues $[80,81]$.

Pit-1 is a pituitary-specific transcription factor responsible for pituitary development and hormone expression in mammals and is a member of the POU family of transcription factors that regulate mammalian development. The POU family is so named because the first 3 members identified were Pit-1 and Oct1 (MIM 164175) of mammals, and Unc- 86 of C. elegans. Pit1 contains 2 protein domains, termed POU-specific and POU-homeo, which are both necessary for high affinity DNA binding on genes encoding growth hormone $(\mathrm{GH})$ and prolactin (PRL). Pit1 is also important for regulation of the genes encoding prolactin and thyroid-stimulating hormone beta subunit (TSHB) by thyrotropin-releasing hormone (TRH) and cyclic AMP $[82,83]$. In embryonic rat pituitary Pit-1 and Prop 1 are co-localized in pituitary in as small percentage of cells $(1-10 \%)$ but in postnatal life Pit-1+ cells decline in number whereas no Prop1 cells are in present in adult pituitary [54]. Prop1 is probably downregulated before stem cell differentiation enhances [3].

P57 is a cyclin-dependent kinase inhibitor 1C (p57,Kip2), also known as CDKN1C, is protein which in humans is encoded by the CDKN1C imprinted gene. This cyclin-dependent kinase inhibitor 1C is a tight-binding inhibitor of several G1 cyclin/Cdk complexes and a negative regulator of cell proliferation. Mutations of CDKN1C are implicated in sporadic cancers and Beckwith-Wiedemann syndrome suggesting that it is a tumor suppressor candidate. CDKN1C is a tumor suppressor human gene on chromosome 11 (11p15) and belongs to the cip/kip gene family. It encodes a cell cycle inhibitor that binds to G1 cyclin-CDK complexes [84]. Thus p57KIP2 causes arrest of the cell cycle in G1 phase. P57 expression causes cell arrest of progenitor cells and the switch to another cyclin-dependent kinase inhibitor, p27, to some extent heralding the manifestation of differentiation markers to preclude re-entry of differentiated cells into the cell cycle [85]. High levels of p57 (CDKN1C) mRNA has also been found in the adult SC-SP which may point to a similar role for p57 in the stem cell compartment of the adult pituitary gland [25].

Cancer stem cells (CSCs) are cancer cells (found within tumors or hematological cancers) that possess characteristics associated with normal stem cells, specifically the ability to give rise to all cell types found in a particular cancer sample. Therefore CSCs are tumorigenic (tumor-forming), conceivably in contrast to other non-tumorigenic cancer cells. CSCs may produce tumors through the stem cell processes of self-renewal and differentiation into multiple cell types. Such cells are proposed to persist in tumors as a distinct population and cause relapse and metastasis by giving rise to new tumors. Therefore, development of specific therapies targeted at CSCs holds hope for improvement of survival and quality of life of cancer patients, especially for sufferers of metastatic disease. As CSCs would form a very small proportion of the tumor, this may not necessarily select for drugs that act specifically on the stem cells. The theory suggests that conventional chemotherapies kill differentiated or differentiating cells, which form the bulk of the tumor but are unable to generate new cells. A population of CSCs, which gave rise to it, could remain untouched and cause a relapse of the disease. In experimental pituitary models mice bearing mutations affecting-catenin proteolysis in the pituitary and leading to constitutive activation of the $\mathrm{WNT} / \beta$ - 
catenin pathway (obtained by crossing a Hesx1-cre knock-in strain to a $\beta$-catenin strain that produces degradation-resistant $\beta$-catenin mutant, upon recombination), developed tumors resembling, as far as histological appearance and marker expression are concerned, human adamantinomatous craniopharyngiomas [86]. Based upon this data, it could be hypothesized that beta-catenin, which controls the balance between self-renewal and differentiation, is inactivated in normal pituitary through altered epigenetic mechanisms may cause sustained progenitor proliferation and eventually tumor development [87]. Importantly, these data strongly support the hypothesis that genetic alterations in pituitary stem/progenitor cells may results in pituitary tumors [88].

\section{Pituitary Stem Cells and Pituitary Neoplasia}

The identification of a classic pituitary stem cell could have major contributions to basic and clinical science. It is hypothesized aberrant proliferation of pituitary stem cells occurs after an abrupt change in the pituitary environment directing to the formation of pituitary adenomas [12,27]. Hitherto only one animal study has explored the role of potential stem cells in pituitary tumorigenesis by using genetic techniques to examine the role that nestin + cells in tumorigenesis. Mice having one functional retinoblastoma allele $(\mathrm{Rb}+/-)$ were crossed with nestin and GFP-positive (Green Protein Fluorescent) mice [21]. The offspring of the cross mice with predominantly produces and releases melanocyte stimulating hormone (MSH) tumors. Unexpectedly none of the tumor cells reacted with nestin; however, nestin+ cells that expressed Lhx3 and SOX-2 in encapsulated the tumors. Based on anatomical propinquity, the authors concluded that nestin+ cells contribute to the initiation of MSH-positive adenomas [21]. In regard to this compelling hypothesis of pituitary tumorigenesis if it would be correct so the suggestions for pituitary adenoma treatment would have been substantial. The other suggestion is if aberrant pituitary stem cells are removed then an indefinite risk subsists for tumor recurrence even though near total resection of adenoma is surgically accomplished. Moreover, if only a unique cell surface marker of aberrant stem cell is identified, then it would be possible to identify the cells with a specific antibody by using immunohistochemical analysis to make certain that the stem cell cohort is removed [89] (Table 2).

Concisely the pituitary is a dynamic organ which undergoes a number of changes in response to physiological stimuli and pituitary microenvironment changes. These subtle changes are thought to be mediated by differentiation of pituitary stem cells. Unlike neural stem cells, pituitary stem cells have not been clearly delineated to a certain cell type, therefore many potential candidates exist. Among this great

\begin{tabular}{|c|c|}
\hline \multicolumn{2}{|c|}{ SM in Pituitary Tumorigenesis } \\
\hline Marker & References \\
\hline E-cadherin(Cdh1) & 3,47 \\
\hline CSC-OCT-4 & $50,51,56,57$ \\
\hline Bmi-1 & 61 \\
\hline CD133 & 68 \\
\hline beta-catenin & $86,87,88$ \\
\hline Sox2/Sox9 & 88 \\
\hline Lhx3 & 21 \\
\hline Sox2 & 21 \\
\hline nestin & 21 \\
\hline
\end{tabular}

Table 2: List of various stemness markers in pituitary tumorigenesis.

\begin{tabular}{|c|c|}
\hline \multicolumn{2}{|c|}{ SM in Pituitary Tumorigenesis } \\
\hline Marker & Ref\# \\
\hline E-cadherin(Cdh1) & 3,47 \\
\hline CSC - OCT-4 & 60,61 \\
\hline Bmi-1 & 66 \\
\hline CD133 & 76 \\
\hline beta-catenin & $82,111-113$ \\
\hline Sox2/Sox9 & 113 \\
\hline Lhx3 & 21 \\
\hline Sox2 & 21 \\
\hline nestin & 21 \\
\hline
\end{tabular}

Table 2: List of various stemness markers in pituitary tumorigenesis.

deal candidates include the chromophobes, folliculostellate cells and marginal cells, the side population cells, SOX2+/SOX9- cells, and GPS cells (GFRa2/Prop1/stem cells). Some authors suppose the current evidence implies that FSCs are the apparently cell type to represent pituitary stem cells. Contribution of pituitary stem cells to pituitary tumorigenes is remains to be further clarified. Due to a large scale of proliferative biomarkers and growth factors involved in proliferation, survival, cell migration and tumorigenesis, cells harboring prominent intracellular signal transducing systems may proceed as paracrine signaling alliance [90]. Hitherto numerous studies confirm the existence of multipotent stem/progenitor cells in the adult pituitary. Even though there is no consensus some characteristics, i.e., Sox $2 /$ SOX-9 expression, SC-SP appear to illustrate identifiable phenotype of these cells. So the upcoming step ahead ought to be corroborating these items in human pituitary pathologies [88]. Unfortunately there is scant support to emphasize that a specific cell type is definitive of a true pituitary stem cell. There has been a considerable amount of studies investigating the potential of folliculostellate cells to act as pituitary stem cells. Nonetheless, forthcoming studies need to undoubtedly clarify the pluripotent capacity of FSCs. Moreover, emerging evidence about the contention of GPS cells and SOX2+/SOX9- cells needs to be investigated further. The implications of the discovery of pituitary stem cells are considerable, and could possibly help improve not only basic information but clinical diagnosis and medical management of pituitary adenomas.

\section{Conclusion}

Discovery of pituitary stem/progenitor cells indisputably expand our understanding of organ specific physiology and pathology. The stem cell data in relation with pituitary neoplasia, cell replacement due to damaging of non-neoplastic conditions and aging of pituitary tissue will undeniably be used in the specific treatment modalities. Currently it is formidable that by using different approaches to stratify and extract intersecting putative stem cells will allow us to manage brand new treatment modalities of diverse pituitary physiologic and pathologic circumstances. Consequently as this miniature magic gland plays a pivotal role in a wide variety of key physiological processes, continuously expanding and fundamental stem cell studies will lead to specific substitution of pituitary stem cells as an incentive step in the regenerative medicine.

\section{References}

1. Rosenfeld MG, Briata P, Dasen J, Gleiberman AS, Kioussi C, et al. (2000) Multistep signaling and transcriptional requirements for pituitary organogenesis in vivo. Recent Prog Horm Res 55: 1-13.

2. Scully KM, Rosenfeld MG (2002) Pituitary development: regulatory codes in mammalian organogenesis. Science 295: 2231-2235. 
Citation: Sav A (2014) Pituitary Stem/Progenitor Cells: Their Enigmatic Roles in Embryogenesis and Pituitary Neoplasia - A Review Article. J Neurol Disord 2: 146. doi:10.4172/2329-6895.1000146

3. Vankelecom H, Chen J (2013) Pituitary stem cells: Where do we stand? Mol Cell Endocrinol

4. Levy A (2008) Stem cells, hormones and pituitary adenomas. J Neuroendocrinol 20: $139-140$

5. Vankelecom $\mathrm{H}$ (2007) Stem cells in the postnatal pituitary? Neuroendocrinology 85: $110-130$.

6. Vankelecom $\mathrm{H}$ (2007) Non-hormonal cell types in the pituitary candidating for stem cell. Semin Cell Dev Biol 18: 559-570.

7. Yoshimura F, Harumiya K, Ishikawa H, Otsuka Y (1969) Differentiation of isolated chromophobes into acidophils or basophils when transplanted into the hypophysiotrophic area of hypothalamus. Endocrinol Jpn 16: 531-540.

8. de Almeida JP, Sherman JH, Salvatori R, Quiñones-Hinojosa A (2010) Pituitary stem cells: review of the literature and current understanding. Neurosurgery 67: 770-780.

9. Beltrami AP, Barlucchi L, Torella D, Baker M, Limana F, et al. (2003) Adult cardiac stem cells are multipotent and support myocardial regeneration. Cell 114: 763-776.

10. Rando TA (2006) Stem cells, ageing and the quest for immortality. Nature 441 1080-1086.

11. Quiñones-Hinojosa A, Chaichana K (2007) The human subventricular zone: a source of new cells and a potential source of brain tumors. Exp Neurol 205: 313-324.

12. Alvarez-Buylla A, Lim DA (2004) For the long run: maintaining germinal niches in the adult brain. Neuron 41: 683-686.

13. Slack JM (2008) Origin of stem cells in organogenesis. Science 322: 14981501.

14. Vankelecom H, Gremeaux L (2010) Stem cells in the pituitary gland: A burgeoning field. Gen Comp Endocrinol 166: 478-488.

15. Levy A (2002) Physiological implications of pituitary trophic activity. J Endocrino 174: 147-155.

16. Borrelli E, Heyman RA, Arias C, Sawchenko PE, Evans RM (1989) Transgenic mice with inducible dwarfism. Nature 339: 538-541.

17. Nolan LA, Kavanagh E, Lightman SL, Levy A (1998) Anterior pituitary cel population control: basal cell turnover and the effects of adrenalectomy and dexamethasone treatment. J Neuroendocrinol 10: 207-215.

18. Wilson DB (1986) Distribution of $3 \mathrm{H}$-thymidine in the postnatal hypophysis of the C57BL mouse. Acta Anat (Basel) 126: 121-126.

19. Fauquier T, Rizzoti K, Dattani M, Lovell-Badge R, Robinson IC (2008) SOX2 expressing progenitor cells generate all of the major cell types in the adult mouse pituitary gland. Proc Natl Acad Sci U S A 105: 2907-2912.

20. Gleiberman AS, Michurina T, Encinas JM, Roig JL, Krasnov P, et al. (2008) Genetic approaches identify adult pituitary stem cells. Proc Natl Acad Sci U S A 105: 6332-6337.

21. Chen J, Hersmus N, Van Duppen V, Caesens P, Denef C, et al. (2005) The adult pituitary contains a cell population displaying stem/progenitor cell and early embryonic characteristics. Endocrinology 146: 3985-3998.

22. Sav A, Rotondo F, Syro LV, Scheithauer BW, Kovacs K (2012) Biomarkers of pituitary neoplasms. Anticancer Res 32: 4639-4654.

23. Yunoue S, Arita K, Kawano H, Uchida H, Tokimura H, et al. (2011) Identification of CD133+ cells in pituitary adenomas. Neuroendocrinology 94: 302-312.

24. Vankelecom H (2010) Pituitary stem/progenitor cells: embryonic players in the adult gland? Eur J Neurosci 32: 2063-2081.

25. Otsuka Y, Ishikawa H, Omoto T, Takasaki Y, Yoshimura F (1971) Effect of CRF on the morphological and functional differentiation of the cultured chromophobes isolated from rat anterior pituitaries. Endocrinol Jpn 18: 133-153.

26. Melmed S (2003) Mechanisms for pituitary tumorigenesis: the plastic pituitary. J Clin Invest 112: 1603-1618.

27. Mogi C, Miyai S, Nishimura Y, Fukuro H, Yokoyama K, et al. (2004) Differentiation of skeletal muscle from pituitary folliculo-stellate cells and endocrine progenitor cells. Exp Cell Res 292: 288-294.

28. Lloyd RV, Hardin H, Montemayor-Garcia C, Rotondo F, Syro LV, et al. (2013) Stem cells and cancer stem-like cells in endocrine tissues. Endocr Pathol 24: 1-10.
29. Horvath E, Kovacs K, Penz G, Ezrin C (1974) Origin, possible function and fate of "follicular cells" in the anterior lobe of the human pituitary. Am J Patho 77: 199-212.

30. Horvath E, Kovacs K (2002) Folliculo-stellate cells of the human pituitary: a type of adult stem cell? Ultrastruct Pathol 26: 219-228.

31. Cocchia D, Miani N (1980) Immunocytochemical localization of the brainspecific S-100 protein in the pituitary gland of adult rat. J Neurocytol 9: 771-782.

32. Nakajima T, Yamaguchi $\mathrm{H}$, Takahashi K (1980) S100 protein in folliculostellate cells of the rat pituitary anterior lobe. Brain Res 191: 523-531.

33. Velasco ME, Roessmann U, Gambetti P (1982) The presence of glial fibrillary acidic protein in the human pituitary gland. J Neuropathol Exp Neurol 41: 150-163.

34. Roncaroli F, Scheithauer BW, Cenacchi G, Horvath E, Kovacs K, et al. (2002) 'Spindle cell oncocytoma' of the adenohypophysis: a tumor of folliculostellate cells? Am J Surg Pathol 26: 1048-1055

35. Riss D, Jin L, Qian X, Bayliss J, Scheithauer BW, et al. (2003) Differential expression of galectin-3 in pituitary tumors. Cancer Res 63: 2251-2255.

36. Allaerts W, Fluitsma DM, Hoefsmit EC, Jeucken PH, Morreau H, et al. (1996) Immunohistochemical, morphological and ultrastructural resemblance between dendritic cells and folliculo-stellate cells in normal human and rat anterior pituitaries. J Neuroendocrinol 8: 17-29.

37. Asa SL, Kovacs K, Horvath E, Losinski NE, Laszlo FA, et al. (1988) Human fetal adenohypophysis: electron microscopic and ultrastructural immunocytochemical analysis. Neuroendocrinology 48: 423-431.

38. Horvath E, Coire Cl, Kovacs K, Smyth HS (2010) Folliculo-stellate cells of the human pituitary as adult stem cells: examples of their neoplastic potential. Ultrastruct Pathol 34: 133-139.

39. Horvath E, Scheithauer BW, Kovacs K, Lloyd RV (2002) Hypothalamus and pituitary. In: Greendfield's Neuropathology, Vol 1, ( $7^{\text {th }}$ edn) (Graham DI and Lantos PL, (eds.)) New York: Arnold.

40. Chen J, Gremeaux L, Fu Q, Liekens D, Van Laere S, et al. (2009) Pituitary progenitor cells tracked down by side population dissection. Stem Cells 27 $1182-1195$.

41. Garcia-Lavandeira M, Quereda V, Flores I, Saez C, Diaz-Rodriguez E, et al (2009) A GRFa2/Prop1/stem (GPS) cell niche in the pituitary. PLoS One 4 e4815.

42. Krylyshkina O, Chen J, Mebis L, Denef C, Vankelecom H (2005) Nestinimmunoreactive cells in rat pituitary are neither hormonal nor typical folliculostellate cells. Endocrinology 146: 2376-2387.

43. Lepore AC, Neuhuber B, Connors TM, Han SS, Liu Y, et al. (2006) Long-term fate of neural precursor cells following transplantation into developing and adult CNS. Neuroscience 142: 287-304

44. Semb H, Christofori $\mathrm{G}$ (1998) The tumor-suppressor function of E-cadherin. Am J Hum Genet 63: 1588-1593.

45. Wong AS, Gumbiner BM (2003) Adhesion-independent mechanism for suppression of tumor cell invasion by E-cadherin. J Cell Biol 161: 1191-1203.

46. Weinberg RA (2006). The Biology of Cancer. Garland Science.

47. Gremeaux L, Fu Q, Chen J, Vankelecom H (2012) Activated phenotype of the pituitary stem/progenitor cell compartment during the early-postnatal maturation phase of the gland. Stem Cells Dev 21: 801-813.

48. Donato R (2003) Intracellular and extracellular roles of S100 proteins. Microsc Res Tech 60: 540-551.

49. Allaerts W, Vankelecom $\mathrm{H}$ (2005) History and perspectives of pituitary folliculostellate cell research. Eur J Endocrinol 153: 1-12.

50. Morris J, Christian H (2011) Folliculo-stellate cells: paracrine communicators in the anterior pituitary. The Open Neuroendocrinology Journal 4: 77-89.

51. Wu W, Cogan JD, Pfäffle RW, Dasen JS, Frisch H, et al. (1998) Mutations in PROP1 cause familial combined pituitary hormone deficiency. Nat Genet 18 147-149.

52. Ward RD, Raetzman LT, Suh H, Stone BM, Nasonkin IO, et al. (2005) Role of PROP1 in pituitary gland growth. Mol Endocrinol 19: 698-710.

53. Yoshida S, Kato T, Susa T, Cai LY, Nakayama M, et al. (2009) PROP1 coexists with SOX2 and induces PIT1-commitment cells. Biochem Biophys Res Commun 385: 11-15. 
Citation: Sav A (2014) Pituitary Stem/Progenitor Cells: Their Enigmatic Roles in Embryogenesis and Pituitary Neoplasia - A Review Article. J Neurol Disord 2: 146. doi:10.4172/2329-6895.1000146

54. Sanicola M, Hession C, Worley D, Carmillo P, Ehrenfels C, et al. (1997) Glial cell line-derived neurotrophic factor-dependent RET activation can be mediated by two different cell-surface accessory proteins. Proc Natl Acad Sci U S A 94: 6238-6243.

55. Takeda J, Seino S, Bell GI (1992) Human Oct3 gene family: cDNA sequences, alternative splicing, gene organization, chromosomal location, and expression at low levels in adult tissues. Nucleic Acids Res 20: 4613-4620.

56. Niwa H, Miyazaki J, Smith AG (2000) Quantitative expression of Oct-3/4 defines differentiation, dedifferentiation or self-renewal of ES cells. Nat Gene 24: 372-376.

57. Tai MH, Chang CC, Kiupel M, Webster JD, Olson LK, et al. (2005) Oct4 expression in adult human stem cells: evidence in support of the stem cell theory of carcinogenesis. Carcinogenesis 26: 495-502.

58. Lengner CJ, Camargo FD, Hochedlinger K, Welstead GG, Zaidi S, et al. (2007) Oct4 expression is not required for mouse somatic stem cell self-renewal. Cell Stem Cell 1: 403-415.

59. Lengner CJ, Welstead GG, Jaenisch R (2008) The pluripotency regulator Oct4: a role in somatic stem cells? Cell Cycle 7: 725-728.

60. Zangrossi S, Marabese M, Broggini M, Giordano R, D'Erasmo M, et al. (2007) Oct-4 expression in adult human differentiated cells challenges its role as a pure stem cell marker. Stem Cells 25: 1675-1680.

61. Haupt Y, Bath ML, Harris AW, Adams JM (1993) bmi-1 transgene induces lymphomas and collaborates with myc in tumorigenesis. Oncogene 8: 3161 3164.

62. Park IK, Qian D, Kiel M, Becker MW, Pihalja M, et al. (2003) Bmi-1 is required for maintenance of adult self-renewing haematopoietic stem cells. Nature 423 302-305.

63. Molofsky AV, Pardal R, Iwashita T, Park IK, Clarke MF, et al. (2003) Bmi-1 dependence distinguishes neural stem cell self-renewal from progenitor proliferation. Nature 425: 962-967.

64. Hemmati HD, Nakano I, Lazareff JA, Masterman-Smith M, Geschwind DH, et al. (2003) Cancerous stem cells can arise from pediatric brain tumors. Proc Nat Acad Sci U S A 100: 15178-15183.

65. Westerman BA, Blom M, Tanger E, van der Valk M, Song JY, et al. (2012) GFAP-Cre-mediated transgenic activation of Bmi1 results in pituitary tumors. PLoS One 7: e35943.

66. Shimizu K, Itoh T, Shimizu M, Ku Y, Hori Y (2009) CD133 expression pattern distinguishes intraductal papillary mucinous neoplasms from ductal adenocarcinomas of the pancreas. Pancreas 38: e207-214

67. Bertolini G, Roz L, Perego P, Tortoreto M, Fontanella E, et al. (2009) Highly tumorigenic lung cancer CD133+ cells display stem-like features and are spared by cisplatin treatment. Proc Natl Acad Sci U S A 106: 16281-16286.

68. Salnikov AV, Gladkich J, Moldenhauer G, Volm M, Mattern J, et al. (2010) CD133 is indicative for a resistance phenotype but does not represent a prognostic marker for survival of non-small cell lung cancer patients. Int $J$ Cancer 126: 950-958.

69. Corbeil D, Röper K, Hellwig A, Tavian M, Miraglia S, et al. (2000) The human AC133 hematopoietic stem cell antigen is also expressed in epithelial cells and targeted to plasma membrane protrusions. J Biol Chem 275: 5512-5520.

70. Sanai N, Alvarez-Buylla A, Berger MS (2005) Neural stem cells and the origin of gliomas. N Engl J Med 353: 811-822.

71. Mizrak D, Brittan M, Alison M (2008) CD133: molecule of the moment. J Patho 214: 3-9.

72. Singh SK, Clarke ID, Terasaki M, Bonn VE, Hawkins C, et al. (2003) Identification of a cancer stem cell in human brain tumors. Cancer Res 63: 5821-5828.

73. Galli R, Binda E, Orfanelli U, Cipelletti B, Gritti A, et al (2004) Isolation and characterization of tumorigenic, stem-like neural precursors from human glioblastoma. Cancer Res 64: 7011-7021.

74. Wang J, Sakariassen PØ, Tsinkalovsky O, Immervoll H, Bøe SO, et al. (2008) CD133 negative glioma cells form tumors in nude rats and give rise to CD133 positive cells. Int J Cancer 122: 761-768.

75. Xu Q, Yuan X, Tunici P, Liu G, Fan X, et al. (2009) Isolation of tumour stem-like cells from benign tumours. $\mathrm{Br} \mathrm{J}$ Cancer 101: 303-311.
76. Kraus C, Liehr T, Hülsken J, Behrens J, Birchmeier W, et al. (1994) Localization of the human beta-catenin gene (CTNNB1) to 3p21: a region implicated in tumor development. Genomics 23: 272-274.

77. MacDonald BT, Tamai K, He X (2009) Wnt/beta-catenin signaling: components, mechanisms, and diseases. Dev Cell 17: 9-26.

78. Peifer M, Rauskolb C, Williams M, Riggleman B, Wieschaus E (1991) The segment polarity gene armadillo interacts with the wingless signaling pathway in both embryonic and adult pattern formation. Development 111: 1029-1043.

79. Noordermeer J, Klingensmith J, Perrimon N, Nusse R (1994) dishevelled and armadillo act in the wingless signalling pathway in Drosophila. Nature 367: 80-83.

80. Peifer M, Berg S, Reynolds AB (1994) A repeating amino acid motif shared by proteins with diverse cellular roles. Cell 76: 789-791.

81. Gueorguiev M, Grossman AB (2009) Pituitary gland and beta-catenin signaling from ontogeny to oncogenesis. Pituitary 12: 245-255.

82. Haegel H, Larue L, Ohsugi M, Fedorov L, Herrenknecht K, et al. (1995) Lack of beta-catenin affects mouse development at gastrulation. Development 121 3529-3537.

83. Sokol SY (2011) Maintaining embryonic stem cell pluripotency with Wnt signaling. Development 138: 4341-4350.

84. Schneider S, Steinbeisser H, Warga RM, Hausen P (1996) Beta-catenin translocation into nuclei demarcates the dorsalizing centers in frog and fish embryos. Mech Dev 57: 191-198.

85. Larabell CA, Torres M, Rowning BA Yost C, Miller JR, et al. (1997) Establishment of the dorso-ventral axis in Xenopus embryos is presaged by early asymmetries in beta-catenin that are modulated by the Wnt signaling pathway. J Cell Biol 136: 1123-1136.

86. Kelly GM, Erezyilmaz DF, Moon RT (1995) Induction of a secondary embryonic axis in zebrafish occurs following the overexpression of beta-catenin. Mech Dev 53: 261-273.

87. Rizzino A (2009) Sox2 and Oct-3/4: a versatile pair of master regulators that orchestrate the self-renewal and pluripotency of embryonic stem cells. Wiley Interdiscip Rev Syst Biol Med 1: 228-236.

88. Graham V, Khudyakov J, Ellis P, Pevny L (2003) SOX2 functions to maintain neural progenitor identity. Neuron 39: 749-765.

89. Suh H, Consiglio A, Ray J, Sawai T, D'Amour KA, et al. (2007) In vivo fate analysis reveals the multipotent and self-renewal capacities of Sox2+ neural stem cells in the adult hippocampus. Cell Stem Cell 1: 515-528.

90. Kim JB, Zaehres H, Wu G, Gentile L, Ko K, et al. (2008) Pluripotent stem cells induced from adult neural stem cells by reprogramming with two factors. Nature 454: 646-650.

91. Walcher T, Xie Q, Sun J, Irmler M, Beckers J, et al (2013) Functional dissection of the paired domain of Pax6 reveals molecular mechanisms of coordinating neurogenesis and proliferation. Development 140: 1123-1136.

92. Cohen LE, Radovick S (2002) Molecular basis of combined pituitary hormone deficiencies. Endocr Rev 23: 431-442.

93. Drouin J (2006) Molecular mechanisms of pituitary differentiation and regulation: implications for hormone deficiencies and hormone resistance syndromes. Front Horm Res 35: 74-87.

94. Raetzman LT, Ward R, Camper SA (2002) Lhx4 and Prop1 are required for cell survival and expansion of the pituitary primordia. Development 129:4229 4239

95. Raetzman LT, Ross SA, Cook S, Dunwoodie SL, Camper SA, et al. (2004) Developmental regulation of Notch signaling genes in the embryonic pituitary: Prop1 deficiency affects Notch2 expression. Dev Biol 265: 329-340.

96. Zhu X, Lin CR, Prefontaine GG, Tollkuhn J, Rosenfeld MG (2005) Genetic control of pituitary development and hypopituitarism. Curr Opin Genet Dev 15: 332-340.

97. Zhu X, Zhang J, Tollkuhn J, Ohsawa R, Bresnick EH, et al. (2006) Sustained Notch signaling in progenitors is required for sequential emergence of distinct cell lineages during organogenesis. Genes Dev 20: 2739-2753.

98. Larsson C, Lardelli M, White I, Lendahl U (1994). The human NOTCH1, 2 and 3 genes are located at chromosome positions 9q34, 1p13-p11, and $19 \mathrm{p} 13.2-\mathrm{p} 13.1$ in regions of neoplasia-associated translocation. Genomics 24 253-258. 
Citation: Sav A (2014) Pituitary Stem/Progenitor Cells: Their Enigmatic Roles in Embryogenesis and Pituitary Neoplasia - A Review Article. J Neurol Disord 2: 146. doi:10.4172/2329-6895.1000146

99. Chen J, Crabbe A, Van Duppen V, Vankelecom H (2006) The notch signaling system is present in the postnatal pituitary: marked expression and regulatory activity in the newly discovered side population. Mol Endocrinol 20: 3293-3307.

100. Tando Y, Fujiwara K, Yashiro T, Kikuchi M (2013) Localization of Notch signaling molecules and their effect on cellular proliferation in adult rat pituitary. Cell Tissue Res 351: 511-519.

101. Sugaya K, Fukagawa T, Matsumoto K, Mita K, Takahashi E, et al. (1994) Three genes in the human MHC class III region near the junction with the class II: gene for receptor of advanced glycosylation end products, PBX2 homeobox gene and a notch homolog, human counterpart of mouse mammary tumor gene int-3. Genomics 23: 408-419.

102. Goldberg LB, Aujla PK, Raetzman LT (2011) Persistent expression of activated Notch inhibits corticotrope and melanotrope differentiation and results in dysfunction of the HPA axis. Dev Biol 358: 23-32.

103.Dabdoub A, Puligilla C, Jones JM, Fritzsch B, Cheah KS, et al. (2008) Sox2 signaling in prosensory domain specification and subsequent hair cell differentiation in the developing cochlea. Proc Natl Acad Sci U S A 105 18396-18401.

104. Basak O, Giachino C, Fiorini E, Macdonald HR, Taylor V (2012) Neurogenic subventricular zone stem/progenitor cells are Notch1-dependent in their active but not quiescent state. J Neurosci 32: 5654-5666.

105. Conboy IM, Rando TA (2002) The regulation of Notch signaling controls satellite cell activation and cell fate determination in postnatal myogenesis. Dev Cell 3: 397-409.

106.Dasen JS, O’Connell SM, Flynn SE, Treier M, Gleiberman AS, et al. (1999)
Reciprocal interactions of Pit1 and GATA2 mediate signaling gradient-induced determination of pituitary cell types. Cell $97: 587-598$.

107. Szeto DP, Ryan AK, O'Connell SM, Rosenfeld MG (1996) P-OTX: a PIT-1interacting homeodomain factor expressed during anterior pituitary gland development. Proc Natl Acad Sci U S A 93: 7706-7710.

108. Matsuoka S, Edwards MC, Bai C, Parker S, Zhang P, et al. (1995) p57KIP2, a structurally distinct member of the p21CIP1 Cdk inhibitor family, is a candidate tumor suppressor gene. Genes Dev 9: 650-662.

109. Bilodeau S, Roussel-Gervais A, Drouin J (2009) Distinct developmental roles of cell cycle inhibitors p57Kip2 and p27Kip1 distinguish pituitary progenitor cell cycle exit from cell cycle reentry of differentiated cells. Mol Cell Biol 29 1895-1908.

110. Gaston-Massuet C, Andoniadou CL, Signore M, Jayakody SA, Charolidi N, et al. (2011) Increased Wingless (Wnt) signaling in pituitary progenitor/stem cells gives rise to pituitary tumors in mice and humans. Proc Natl Acad Sci U S A 108: 11482-11487.

111. Camper SA (2011) Beta-catenin stimulates pituitary stem cells to form aggressive tumors. Proc Natl Acad Sci U S A 108: 11303-11304.

112. Florio T (2011) Adult pituitary stem cells: from pituitary plasticity to adenoma development. Neuroendocrinology 94: 265-277.

113. Nassiri F, Cusimano M, Zuccato JA, Mohammed S, Rotondo F, et al. (2013) Pituitary stem cells: candidates and implications. Pituitary 16: 413-418.

114. Colli LM, Saggioro F, Serafini LN, Camargo RC, Machado HR, et al. (2013) Components of the canonical and non-canonical Wnt pathways are not misexpressed in pituitary tumors. PLoS One 8: e62424.
This article was originally published in a special issue, Frontiers in Stem cells for Neurological Disorders handled by Editor(s). Dr. Kuldip Sidhu, University of New South Wales, Australia 